\title{
Enhancement of biological approach and potential of Lactobacillus delbrueckii in decolorization of textile wastewater - A review
}

\author{
Nur Hazirah R. ${ }^{1}$, Nurhaslina C.R. ${ }^{2}$, Ku Halim K.H. ${ }^{3}$ \\ ${ }^{1,2,3}$ (Faculty of Chemical Engineering, Universiti Teknologi Mara Malaysia, 40450 Shah Alam, Selangor)
}

\begin{abstract}
Dyes used in textile fabric as a coloring agent is not an operative technique since it is produced highly colored wastewater. The colored wastewater was produced from dyeing process in textile manufacturing process. The pollution of color in aquatic ecosystem is a rising problem nowadays. Currently, the technique to remove the color from textile wastewater are mostly studied worldwide as an awareness concerns since there are no specific solution has been acceptable for treating the broad diversity of textile wastewater. There has been an extensive research into the implementation of the modification and development of the biological treatment using bacteria with suitable matrix for immobilization process that can improve the decolorization rate of textile wastewater. The usage of immobilized microbial cells in the field of wastewater treatment has been found to be useful. Hence, the review presented here concerns the improvement of biological approach using bacteria with bamboo as matrix for immobilization in reduction of dyes present in textile wastewater.
\end{abstract}

Keywords: Lactobacillus Delbrueckii, Bamboo, Bacterial host, Decolorization, Textile wastewater

\section{Introduction}

The usages of synthetic dyes are one amongst the main chemical pollutants that invent commonly from printing, painting, textile, food and plastic industries [1]. Textile industries are most frequent industries that used a lot of synthetic dyes in their manufacturing process that contribute to the discharging of color wastewater [2]. Synthetic dyes are given serious affectation health hazards to the entire ecosystem especially aquatic life and human beings [3]. These dyes are remarkably unaffected by degradation and decolorization using physical or chemical approaches including ozonation, oxidation, ion exchange, adsorption, precipitation or membrane separation $[2,3]$. The treatment technologies of physicochemical technique are well-known in this industry but it is need substantial start-up costs and cannot meet increasingly strict wastewater color standards due to the low biodegradability of dyes [4].

The release of an extensive variety of synthetic dyes produced by altered industries to ecosystems made this topic as a major environmentally friendly problem [4]. In aquatic ecologies, the appearance of dyes reduces the oxygen level due to decreasing amount of sunlight for photosynthetic organisms [5]. Some of these dyes are xenobiotic, toxic and carcinogen element in nature and originate to be recalcitrant $[5,6]$. There is a persistent requirement for enlargement of eco-friendly biotechnology treatment approach for decolorization of dyes wastewater. A number of studies reported in literature on bio-decolorization of dyes using microorganisms show the abilities in decolorization of dye [7]. Biological approaches offer an alternative technology to replace the existing technologies which are expensive, commercially and environmentally unattractive [7, 8].

The biological approaches are cost effective, eco-friendly system and can be useful to decolorize wide range of dye contain in industrial wastewater $[3,5]$. Biological approach by employing microbe is found to be adeptly removing dyes from large capacities of wastewater with low-cost as the microorganism's role is to degrade the organic matter [6, 7]. A variety of microorganisms used including bacteria such as Escherichia coli, Bacillus cereus, Sphaerotilus natans, Bacillus coagulans, Bacillus subtilis and Pseudomonas pseudomallei are capable in decolorizing a wide range of dyes through aerobic, anaerobic and sequential anaerobic-aerobic treatment processes [9]. However, researchers are emerging to identify new bacteria that can be used as alternate to decolorize of dye from textile wastewater.

Many efforts have been made for improvement of biological treatment processes using bacteria. The prospective studies are focused on the development and enhancement of biological process for textile wastewater using bacteria by introducing bamboo as matrix for immobilization process. [11]. However, sequence of scientific studies being used as an important implementation in the alteration and development of new biological technologies focusing on environmentally friendly mode [10, 11]. Currently, the bacteria, Lactobacillus delbrueckii was studied to improve and modify by immobilized on the bamboo and applied in decolorization process of synthetic dyes and real textile wastewater [12]. The bacteria, Lactobacillus delbrueckii are used as it has capability to aerobically degrade such pollutants by feature of its extracellular lactic acid 
bacteria, LAB. Moreover, the influences of surrounding parameters such as temperature, dye concentration, bacterial dosage, interaction time and $\mathrm{pH}$ on dye decolorization were further investigated.

\section{Wastewater Treatment Technologies Available for Decolorization Process - The Advantages and Disadvantages}

The major environmental issue in textile industries is wastewater besides other minor issues such as solid waste, air pollution, safety and store consumption $[8,9]$. Textile manufacturing process uses many types of artificial composite dyes and discharges large volume of highly colored wastewater [13]. Textile industry involves with a few step such as pretreatment and dyeing of fibers that usually require variety of chemical and large amounts of water $[12,13]$. The quality of fabrics and treatment process are differs that resulting into large fluctuation in daily flow rate and pollutant concentration [14]. The wastewater pollutants from textile industry are generally consists of starch, wax, urea, ammonia, pigments and dyes that increase its turbidity, toxicity, BOD and COD $[14,15]$. All of the wastewater produces must be treated first before discharges in order to comply with the industrial effluent standard given by environmental law.

There are many technologies existing for treating the textile effluent. The option of treatment generally can be divided into three main classifications namely physical, chemical and biological approach [15]. The physical methods used such as membrane filtration process gives demerit related with membrane fouling problem, limited lifetime and the rate of periodic replacement must be counted in any economic feasibility analysis $[15,16]$. Coagulation, flocculation and oxidation process are such as examples in chemical method. These chemical techniques are successful in removal of dyes, but these approaches are costly and create a disposal problem [16]. However, the biological treatment is the most cost-effective options when compared with physical and chemical processes. Biodecolorization methods such as fungal or bacterial decolorization by microbial biomass are commonly applied to treat the industrial effluents, since various microorganisms such as fungi, bacteria, yeasts and algae are capable to degrade different dyes in colored wastewater [17].

The technologies often used in dye decolorization process of textile effluent are physical and chemical approach $[15,16]$. Some examples of physical and chemical approaches are summarized in Table 1. Technologies method of physical and chemical are well-known in this industry but it is less efficiency, very costly and limited applicability due to the low biodegradability of dyes [9, 10]. Other developing methods such as oxidation, adsorption, ion exchange, ozonation, coagulants, membrane separation and photochemical may have potential for decoloration of colored wastewater [16]. But, such treatment technologies generally involve with complex procedures and economically impracticable.

In the past several decades, many techniques have been developed to find an economic and efficient way to treat the colored wastewater from textile industry including biochemical, physicochemical, combined treatment processes and other approaches [16]. The treatment technologies approaches are mainly highly efficient for treated of colored wastewater. Studies focusing on feasibility of treating colored wastewater are very important. As study by Ponraj et al. [8], it has found that biological treatment systems as preferable alternative that can effectively remove dyes from large volumes of wastewater at a low cost. Biological method is more preferable because it is environmental friendly and economical attractive $[10,15]$.

Table 1: The advantages and disadvantages of physical chemical treatment technologies

\begin{tabular}{lll}
\hline $\begin{array}{l}\text { Physical and chemical } \\
\text { treatment methods }\end{array}$ & Advantages & Disadvantages \\
\hline Membrane separation & Can decolorize all types of chemical class dye. & $\begin{array}{l}\text { Sludge generation incapable for large scale treatment, } \\
\text { expensive, high pressure. }\end{array}$ \\
\hline Ion exchange & Operative with no loss of regeneration. & $\begin{array}{l}\text { Not effective for dispense dyes. Possible economic } \\
\text { constraints during regeneration. }\end{array}$ \\
\hline Ozonation & $\begin{array}{l}\text { Applied in gaseous state, no toxic metabolites } \\
\text { complete COD. }\end{array}$ & $\begin{array}{l}\text { Short half-life, stability affected by auxiliary } \\
\text { chemicals expensive. }\end{array}$ \\
\hline Oxidation & Rapid and proficient process & $\begin{array}{l}\text { Chemical required, high energy cost, by products } \\
\text { production. }\end{array}$ \\
\hline Coagulant/Flocculants & Simple, economically feasible & $\begin{array}{l}\text { High amount sludge production, high amount } \\
\text { chemicals required for PH adjustment. }\end{array}$ \\
\hline $\begin{array}{l}\text { Adsorption on activated } \\
\text { carbon }\end{array}$ & Effective, high capacity. & $\begin{array}{l}\text { Regeneration is expensive, loss of absorbent, } \\
\text { ineffective against disperse and vat dye. }\end{array}$ \\
\hline Photochemical & No sludge production, foul odours are not produced & Secondary pollutants \\
\hline Electrolysis & Varying degree of success in colour removal & $\begin{array}{l}\text { Generate undesirable by products } \\
\text { Not tested on full scale operation }\end{array}$ \\
\hline $\begin{array}{l}\text { Fenton Reagents } \\
\text { Activated carbon }\end{array}$ & Effective decolorization for soluble and insoluble dyes & Sludge generation \\
\hline $\begin{array}{l}\text { Electrokinetic } \\
\text { coagulation }\end{array}$ & Good elimination of a variety of dyes & Very costly \\
\hline $\begin{array}{l}\text { Sources: } \\
\text { Economically feasible }\end{array}$ & Produce high sludge
\end{tabular}

(Sources: Monika, 2011 [17]; Andre et. al.[15], 2007; Ester et. al., 2004 [16]) 


\section{Decolorization Process of Textile Wastewater using Bacteria, Lactobacillus Delbrueckii}

Wastewater treatment using biological approach is one of the technologies apply in textile wastewater, though physical and chemical approach. As the physicochemical technologies has some drawback, it is inspires researches to develop with other alternate treatment technologies [17]. Based on literature survey, it is proposes biological approach using microorganism as the most favourable method to deal with textile wastewater $[8,9$, 17]. The effectiveness of microorganism to eliminate dye from textile wastewater has been verified as the microorganism itself used to degrade the organic substance [18]. The efficiency of the biological method depends on the capability and performance of the microorganism itself [8].

Altered microorganism species used will give different reaction to degrade dye in textile wastewater. According to Ponraj et al. [8], a lot of microorganism that had potential to improve the effectiveness of decolorization is still available but not been established yet. The most recent bacteria found currently in decolorize of textile wastewater is Lactobacillus delbrueckii. The effectiveness of decolorization of textile wastewater using Lactobacillus delbrueckii has been study by previous researcher as summarized in Table 2 . Since these bacteria are still new finding in this wastewater treatment technologies field, less study are found before.

Lactobacillus delbrueckii is a group of bacteria lies under lactic acid bacteria (LAB) and genus of lactobacillus contain a various group of 140 species [14]. The genus of lactobacillus is one of the largest groups of lactic acid bacteria used in food fermentation processes and commonly used in manufacturing of yogurt [14]. Lactobacillus delbrueckii are classified as gram-positive, catalyse negative, non-motile, non-sporulation and facultative anaerobes [7]. As Lactobacillus group produce lactic acid bacteria (LAB), interest in decolorization of dye from textile wastewater using lactic acid bacteria has been studies [11].

Lately, there are a few reports about lactic acid bacteria ability to degrade azo dyes has been published. Previous study by Phisit et al. [9] had proved that Lactobacillus casei capable to decolorize dye which shows that lactic acid bacteria have talent to decolorize of dye from textile wastewater [13]. According to Siti Zuraida M. et al. [12], synthetic dye can be eliminating using Lactobacillus delbrueckii at maximum rate decolorization of $57 \%$. Different study using batik wastewater by the same author, Siti Zuraida M. et al [11, 12], shows the performance of Lactobacillus delbrueckii in color removal of batik wastewater, 52\%, at the optimum condition.

The performances of lactic acid bacteria, Lactobacillus delbruckii will be used in dye decolorization process of textile wastewater by evaluate their capability on decolorizing the dye solution. Based on the data presented at Table 2, the optimum decolorization of textile wastewater using Lactobacillus delbrueckii about $50-60 \%$ corresponds with the types of dyes used $[11,12]$. Our findings of this research and previous study, indicates that the ability of bacteria to decolorize the textile wastewater can be extensively increased by decrease the dye concentration and optimizing the effective conditions such as nutrient content of the media culture and environmental conditions $[8,10]$. It is obviously shown that the ability of decolorization was different when different bacteria were used for different dyes. More research will progress in future on the decolorization of textile wastewater using efficient strains of bacteria [13].

Table 2: Dye decolorization using bacteria

\begin{tabular}{|c|c|c|c|}
\hline Microorganism & Dye & $\%$ Decolorization & Authors \\
\hline $\begin{array}{l}\text { Consortium bacteria (Sphingomonas } \\
\text { paucimobilis, Bacillus sp. and } \\
\text { filamentous bacteria) }\end{array}$ & Textile wastewaster & $72.48 \%$ & Ayed et al., 2011 [10] \\
\hline $\begin{array}{l}\text { Bacillus sp., } \\
\text { Pseudomonas sp. } \\
\text { Salmonella sp. } \\
\text { Klebsiella sp. } \\
\end{array}$ & Orange $3 R$ & $\begin{array}{l}89 \% \\
89 \% \\
80 \% \\
76 \% \\
\end{array}$ & Ponraj et al., 2011 [8] \\
\hline Lactobacillus delbrueckii & $\begin{array}{c}\text { Reactive orange } 16 \\
\text { Reactive black } 5\end{array}$ & $\begin{array}{l}57 \% \\
51 \% \\
\end{array}$ & Siti Zuraida et al., 2013 [12] \\
\hline $\begin{array}{l}\text { Pseudomonas putida } \\
\text { Bacillus cereus } \\
\text { Bacillus subtilis Pseudomonas } \\
\text { fluorescens }\end{array}$ & Acid Orange 10 & $\begin{array}{l}90 \% \\
65 \% \\
54 \% \\
39 \% \\
\end{array}$ & Tripathi et al., 2011 [13] \\
\hline
\end{tabular}

\section{Mechanism of Immobilized Microbial Cell}

Immobilization in general term defines many dissimilar practices of cell attachment or entrapment [2,3]. It is consists of different form consist of flocculation, adsorption on surfaces, covalent bonding to carriers, cross-linking of cells and entrapment in a matrix [4]. Immobilized microbial enzymes, organelles and cells have been used in a diversity of scientific and industrial application [5]. Immobilization technology has been used comprehensively in commercial fermentation [6]. Various alternate carriers for immobilization process can be used. The exploration for alternative matrix for immobilization process had shown by previous study is shown 
in Table 3. The practice of immobilized microbial cells in the field of wastewater treatment technologies has been found to be useful because of the benefits include with long retention time of biomass in the system, ease of use in a continuous reactor and their ability for scale up [3,4,5].

From Table 3, it had shown the loofa sponge (Luffa cylindrica) as matrix for immobilization of various microorganisms like Candida brassica, Aspergillus niger and Lactococcus lactis. Three different matrices applied in previous study as reported by Engade, et al. [5], for immobilization of Aspergillus terreus were namely loofa sponge (Luffa cylindrica), coconut fibre and groundnut shells. In further investigations, it is suggests textile effluent from a cottage industry was obtained and its decolorization studied using immobilized Lactobacillus delbrueckii.

Table 3: Alternative matrix for immobilization process

\begin{tabular}{cccc}
\hline Types of carrier & Microorganims & \multicolumn{1}{c}{ Dye } & Authors \\
\hline $\begin{array}{c}\text { Loofa sponge }(\text { Luffa } \\
\text { cylindrica) }\end{array}$ & $\begin{array}{c}\text { Aspergillus terreus, Candida brassica, } \\
\text { Aspergillus niger Lactococcus lactis }\end{array}$ & $\begin{array}{c}\text { Mixed dye } \\
\text { (Textile effluent) }\end{array}$ & $\begin{array}{c}\text { Engade et al., 2010 [5]; } \\
\text { Ogbonna J. et al., 1997 [6]. }\end{array}$ \\
\hline $\begin{array}{c}\text { Coconut fibre } \\
\text { Groundnut shell }\end{array}$ & Aspergillus terreus & $\begin{array}{c}\text { Mixed dye } \\
\text { (Textile effluent) }\end{array}$ & Engade et al., 2010 [5] \\
\hline $\begin{array}{c}\text { Porous silica beads } \\
\text { Sol-gel matrix } \\
\text { (manganese peroxidase) }\end{array}$ & Paraconiothyrium variabile & $\begin{array}{c}\text { Acid blue 25 } \\
\text { Acid orange 7 }\end{array}$ & Mirzadeh et al., 2014 [1] \\
\hline
\end{tabular}

\section{Bamboo as a New Matrix in Immobilized Process}

Immobilization of microbial cells in biological methods can occur in a natural phenomenon or through artificial process [6]. The attached cells in natural environment show substantial growth compare with artificially immobilized cells which are permitted restricted growth [6,7]. Numerous immobilization procedures and a few carrier materials were tried by previous study such as coconut fibre, groundnut shell, porous silica beads and loofa sponge $[5,6,7]$. The characteristic of matrix is important in determining the performance of the immobilized process. The ideal properties of matrix include inertness toward enzyme, biocompatibility, resistance to microbial attack and availability at low cost $[7,8]$. The physical characteristic of the matrices is the main important for the performance of the immobilized system such as pore parameters and particle size which determine the total surface area once affect the capacity for binding of enzymes [8, 9].

The findings of innovative alternative, bamboo, as carrier material from nature surroundings are seen to be beneficial for future immobilization process. The use of bamboo as alternative carrier for immobilization can be useful application as it able to growing of microorganism in bamboo tissue. As reported by Olena et al. [19, 20], there was a potential of microorganism attach in bamboo as the analysis was done under field emission scanning electron microscopy (FESEM) where endophytic bacteria in bacillary form were found in intracellular spaces and vessels within the bamboo tissue. Based on literature study, it shows that bamboo had potential to become as housing as it has talent to growing of microorganism previously [18].

\section{Improvement Of Biological Approach Using Lactobacillus Delbrueckii Attach With Bamboo As Carrier For Immobilization Process}

The discovery of innovative findings in treatment of textile wastewater using bamboo as carrier for immobilization become as a new resolution in this field. As bamboo is not only developing as an alternative source for textile fiber, but it is also can be used as carrier for immobilization due to its superior physical and mechanical properties. The introduction of bamboo are develop new carrier in immobilized microbial cells with Lactobacillus delbrueckii in industrial application for treated of dye from textile wastewater.

\section{Conclusions}

This review demonstrates the great potential of bamboo as matrix in immobilized microbial cell in wastewater treatment systems incorporating with Lactobacillus delbrueckii to metabolize the azo dyes contain in textile wastewater. Under anaerobic conditions, these systems can achieve total color removal with short exposure times. The application of treatment technologies involving immobilized microbial cells with bamboo as matrix is seen to be beneficial in improve and modify the previous study on biological approaches.

\section{Acknowledgements}

The authors acknowledge to the Faculty of Chemical Engineering (FKK), UiTM Malaysia for their support and helps in makes this research successfully by providing equipment used in order to accomplish this research. 


\section{References}

[1]. S.S Mirzadeh, S.M. Khezri, S. Rezaei, H. Forootanfar, A.H Mahvi and M.A Faramarzi, Decolorization of two synthetic dyes using the purified laccase of Paraconiothyrium variabile immobilized on porous silica beads, Journal of Environmental Health Science and Engineering 2014, 12:6

[2]. R.G. Saratale, G.D. Saratale, J.S. Chang, S.P. Govindwar, 2011, Bacterial decolorization and degradation of azo dyes: A revie w., Journal Taiwan Inst Chemical Engineeering, 42:138-157.

[3]. R.O. Cristovao, A.P.M. Tavares, A. Brigida, J.M. Loureiro, R.A.R. Boaventura, E.A. Macedo, M.A.Z. Coelho, 2011, Immobilization of commercial laccase onto green coconut fiber by adsorption and its application for reactive textile dyes degradation, Journal Molecular Catalyst B. 72:6-12.

[4]. H.M.N. Iqbal and M.Asgher, 2013, Decolorization applicability of sol-gel matrix immobilized manganese peroxidase produced from an indigenous white rot fungal strain Ganoderma lucidum, BMC Biotechnology 2013, 13:56

[5]. K.B. Engade, S.G. Gupta, 2010, Decolorization of Textile Effluent by Immobilized Aspergillus terreus, Journal of Petroleum and Environmental Biotechnology 1:101.

[6]. J. Ogbonna, S. Tomiyama, C. Liu and H. Tanaka, 1997, Efficient production of ethanol by cells immobilized in Loofa sponge. Journal of Fermentation and Bioengineering, 84: 271-274.

[7]. R.Ashraf, , P. S., Nagendra, 2011, Selective and differential enumerations of Lactobacillus delbrueckii subsp. bulgaricus, Streptococcus thermophilus, Lactobacillus acidophilus, Lactobacillus casei and Bifidobacterium spp. in yoghurt - A review, International Journal of Food Microbiology 149 (2011) 194-208

[8]. M., Ponraj, K., Gokila and V., Zambare, 2011, Bacterial Decolourization of Textile Dye Orange 3R, International Journal of Advanced Biotechnology and Research, ISSN 0976-2612, 2(1),pp.168-177.

[9]. S., Phisit, T., Shinji, K., K., S., Ampin, M., Shuichiro, \& A., Kenji, 2007, Metabolism of azo dyes by Lactobacillus Cas ei TISTR 1500 and dyes by effects of various facyors on decolorization. Water Research, 41, 985-992.

[10]. L.,Ayed, S.,Achour and A., Bakhrouf, 2011, Application of the mixture design to decolourise effluent textile wastewater using continuous stirred bed reactor, Water SA, 37(1), pp. 21-26.

[11]. M., Siti Zuraida, C.R., Nurhaslina and K.H, Ku Halim, 2009, Influence of Agitation, pH and temperature on Growth and Decolorization of Batik Wastewater by Bacteria, Lactobacillus Delbruckii, IJRRAS 14(2)

[12]. M., Siti Zuraida, C.R., Nurhaslina and K.H, Ku Halim, 2013, Removal of Synthetic Dyes from Wastewater by Using Bacteria, Lactobacillus delbrueckii, International Refereed Journal of Engineering and Science (IRJES), Volume 2, Issue 5(May 2013), pp.01-07

[13]. A.,Tripathi and S.K., Srivastava, 2011, Ecofriendly Treatment of Azo Dyes: Biodecolorization using Bacterial Strains, International Journal of Bioscience, Biochemistry and Bioinformatics, Vol. 1, No. 1, May 2011

[14]. C., Vázquez, J.I., Botella-Carretero, R., García-Albiach, M.J.,Pozuelo, M., Rodríguez-Baños, F., Baquero, M.A.,Baltadjieva and Rosa del Campo, 2013, Screening in a Lactobacillus delbrueckii subsp. Bulgaricus collection to select a strain able to survive to the human intestinal tract Nutrition Hospitalaria 2013;28(4):1227-1235

[15]. B.D.S Andre, J.C. Francisco. B.V.L. Jules, 2007, Review paper on current technologies for decolourisation of textile wastewaters: Perspectives for anaerobic biotechnology, Bioresource Technology 98 (2007) 2369-2385

[16]. F. Esther, C. Tibor, O. Gyula, 2004, Removal of synthetic dyes from wastewaters: a review, Environment International 30 (2004) $953-971$

[17]. Monika Kharub, 2012, Use of various technologies, methods and adsorbents for the removal of dye, Journal of Environmental Research and Development, Vol. 6 No. 3A, Jan-March 2012

[18]. H.,Wang, J., Qiang Su, X.,Wei Zheng,Y.,Tian, X.,Jing Xiong, T.,Ling Zheng,2009, Bacterial decolorization and degradation of the reactive dye Reactive Red 180 by Citrobactersp. CK3, International Biodeterioration \& Biodegradation 63 (2009) 395-399

[19]. V.M., Olena, P.S., Svetlana, A.K., Vitalii, P., Geert, 2012, Visualization of endophytic bacteria in Phyllostachys sp. And Fargesia sp., The Journal of the American Bamboo Society 25(1): 11-18

[20]. V.M., Olena, B., Judicaelle, P.,Geert, 2012, Identification of endophytic bacteria in Phyllostachyssp and Fargesiasp., Journal of the American Bamboo Society 25(1):19-26 